\title{
Characterization of Rice Growing Soil of Nagara Block of Ballia District (U.P.), India
}

\author{
Divakar Singh, Ashok Kumar Singh, Anil Kumar Singh and Sandip Kumar Gupta*
}

Department of Agricultural Chemistry and Soil Science, SMM Town PG College, Ballia-277001 (Jananayak Chandrashekhar University, Ballia), India

*Corresponding author

\section{A B S T R A C T}

\begin{tabular}{l} 
K e y w o r d s \\
$\begin{array}{l}\text { Pedon, Soil organic } \\
\text { carbon, Soil depth, } \\
\text { NPKS content and } \\
\text { Micronutrients }\end{array}$ \\
Article Info \\
$\begin{array}{l}\text { Accepted: } \\
\text { 07 March } 2020 \\
\text { Available Online: } \\
\text { 10 April } 2020\end{array}$ \\
\hline
\end{tabular}

An investigation was carried out for Characterization of rice growing soil of Nagara block of Ballia district, (U.P.) India. Depth wise soil samples were collected from two selected village and in this respect a soil profile was opened in each village. Soil samples were collected from 0-15, 15-30, 30-45, 45-60, 60-75, 75-90, 90-105 and 105-130 soil depth. Standard method was followed for analysis of physico-chemical parameter of soil. Results revealed that $\mathrm{pH}$ of soil found to be slightly alkaline where EC was in normal range. Bulk density of soil found be (1.16 - $\left.1.73 \mathrm{Mg} \mathrm{m}^{-3}\right)$ and water holding capacity contained (20.4 $37.5 \%)$. Organic carbon content varied from $(0.07-0.59 \%)$. The soil was slightly moderately calcareous $\left(0.39-1.37 \mathrm{CaCO}_{3} \%\right)$. Available $\mathrm{N}, \mathrm{P}, \mathrm{K}$, and $\mathrm{S}$ content in soil varied from $\left(142.2-489.8 \mathrm{~kg} \mathrm{ha}^{-1}\right),\left(9.76-15.28 \mathrm{~kg} \mathrm{ha}^{-1}\right),\left(259.6-403.2 \mathrm{~kg} \mathrm{ha}^{-1}\right)$ and $(9.25$ - $\left.16.25 \mathrm{~kg} \mathrm{ha}^{-1}\right)$. Micronutrients $\mathrm{Fe}, \mathrm{Cu}, \mathrm{Zn}$ and $\mathrm{Mn}$ content in soil from (2.37 - 9.02 $\left.\mathrm{mg} \mathrm{kg}{ }^{-1}\right),\left(1.31-9.07 \mathrm{mg} \mathrm{kg}^{-1}\right),\left(0.12-1.22 \mathrm{mg} \mathrm{kg}^{-1}\right)$ and $\left(0.18-4.83 \mathrm{mg} \mathrm{kg}{ }^{-1}\right)$ rang respectively.

\section{Introduction}

Soil test-based fertility management is an effective tool for increasing productivity of agricultural soils that have a high degree of spatial variability resulting from the combined effects of physical, chemical or biological processes (Govaerts, 1998). However, major constraints impede wide scale adoption of soil testing in most developing countries. In India, these include the prevalence of small holding systems of farming as well as the lack of infrastructural facilities for extensive soil testing (Sen et al., 2008). The importance of soil fertility and plant nutrition to the health and survival of all life cannot be understated. As human population continue to increase, human disturbance of the earth's ecosystem to produce food and fiber will place greater demand on soils to supply essential nutrients. Therefore, it is critical that we increase our understanding of the chemical, biological and physical properties and relationships in the soil plant atmosphere continuum that control nutrient availability. Soil is the most valuable natural resource. It is at the heart of terrestrial ecology, but is finite and non-renewable. To meet the challenges of this century, new 
understandings and new technologies will be needed to protect the environment and at the same time, produce food and biomass to support society (Brady and Weil, 2004). Systematic study of morphology and taxonomy of soils provides information on nature and type of soils, their constraints, potentials, capabilities and their suitability for various uses (Sehgal, 1999).

\section{Materials and Methods}

Ballia district, the eastern part of the state of Uttar Pradesh is situated in central portion of the Ganges basin. The geographical extent of the district lies between latitude from $25^{\circ} 23^{\prime \prime}$ to $26^{\circ} 11^{\prime \prime}$ north and at longitudes from $83^{\circ} 38^{\prime \prime}$ to $84^{\circ} 39^{\prime \prime}$ east with elevation of about 27 to 115 meters above the sea level. The mean annual rainfall ranges from 950 to $1150 \mathrm{~mm}$. The district has an area of 1,981 sq. km. Soil samples were air dried in shade and powdered gently with a wooden mallet and passed through $2 \mathrm{~mm}$ sieve. Soil $\mathrm{pH}$ was determined in 1:2.5 soil water suspension using glass electrode. Electrical conductivity (EC) was determined in 1:2.5 soil-water extract using Conductivity Bridge and expressed as $\mathrm{dSm}^{-1}$ (Jackson, 1973). Calcium carbonate (CaCO3) was determined by rapid titration method (Puri, 1930). Bulk density method described by Kanwar and Chopra (1998). Organic carbon (OC) was determined by rapid titration method (Walkley and Black, 1934). Available nitrogen (N) was determined by alkali extractable nitrogen method (Subbiah and Asija, 1956), available phosphorus (P) by Olsen's et al., (1954) and available potash (K) ammonium acetate extractable method described by Muhr et al., (1965). Available sulphur (S) was extracted using 0.15 per cent calcium chloride solution (Williams and Steinbergs, 1969). Micronutrients namely Zn, $\mathrm{Cu}, \mathrm{Fe}$ and $\mathrm{Mn}$ were determined on atomic absorption spectrophotometer as outlined by Lindsay and Norvell (1978).

\section{Results and Discussion}

\section{Soil pH}

The perusal of data in table 1 of soil $\mathrm{pH}$ of two pedon of Nagara Block soil was ranged from 7.4 to 8.1. A very small increasing range of $\mathrm{pH}$ towards alkaline from top soil (0-15 $\mathrm{cm})$ to the lower $(105-130 \mathrm{~cm})$ depth were found in both pedons. Pedon 1 was showed $7.9 \mathrm{pH}$ at $0-15 \mathrm{~cm}$ there after increasing 7.6 at $105-130 \mathrm{~cm}$ soil and pedon 2 was showed 8.1 $\mathrm{pH}$ at $0-15 \mathrm{~cm}$ there after decreasing 7.6 at $105-130 \mathrm{~cm}$. The lower $\mathrm{pH}$ range was found at upper layer of pedon than the $105-130 \mathrm{~cm}$ depth due to presence of organic matter and their higher activity of hydroxyl aluminum at higher $\mathrm{pH}$, eventually resulted in higher $\mathrm{P}$ adsorption (Mokwanye, 1975). The higher biological activities might be responsible for decreased $\mathrm{pH}$ range on surface soil, the $\mathrm{pH}$ value showed in increase with increasing in the depth of soil which is attributed to determine of neutral soluble salt (Abrol, 1998).

\section{Electrical conductivity of soil EC $\left(\mathrm{dSm}^{-1}\right)$}

The data of table 1 revealed that the EC of soil samples from two pedons of Nagara Blcok of soil depth. EC of soil under study ranged from $1.013 \mathrm{dSm}^{-1}$ indicated not wide variation between the two pedons, pedon-1 showed relative low EC $1.002 \mathrm{dSm}^{-1}$ values in surface layer as compared to sub surface (0-$315 \mathrm{~cm})$ soil $1.003 \mathrm{dSm}^{-1}$ at $(0-15 \mathrm{~cm})$ were observed. Difference at pedon-2 which may be ascribed to the lateral movement of water from the construction of earthen band on ground (Mehta etal.1996).

\section{Bulk density (Mg m-3)}

Bulk density of soil was measured by the depth wise soil taken two pedons, presented in table 1. Bulk density was varied between 
value 1.22 to $1.55 \mathrm{Mg} \mathrm{m}^{-3}$ between the pedon1 and pedon-2 respectively. The increased bulk density was observed at pedon-1 with $105-130 \mathrm{~cm}$ depth, $1.55 \mathrm{Mg} \mathrm{m}-3$, pedon-2 at with $0-15 \mathrm{~cm}$ depth, $1.73 \mathrm{Mg} \mathrm{m}^{-3}$ and low value was at pedon 1 with $1.19 \mathrm{Mg} \mathrm{m}^{-3}$ in 60$75 \mathrm{~cm}$ depth. Bulk density values varied from 1.19 to $1.73 \mathrm{Mg} \mathrm{m}^{-3}$ with a small variation between both pedon and between the horizons. The increase in bulk density from upper to lower horizons of all pedon due to translocation of clay and other minerals develop the compaction (Mandal and Sharma, 2011).

\section{Water holding capacity (\%)}

Water holding capacity measured at pedon-1 and pedon- 2 in table 1 which varied from 20.4 $\%$ on $105-130 \mathrm{~cm}$ depth to $37.5 \%$ on surface horizon. WHC value decreased in horizon depth at both pedon. The pedon 1 was showed $19.1 \%$ on $105-130 \mathrm{~cm}$ depth to $37.5 \%$ on 0 $15 \mathrm{~cm}$ surface horizon and pedon 2 was showed $21.6 \%$ on $105-130 \mathrm{~cm}$ to $35.8 \%$ on lower surface horizon. There was great difference of water holding capacity in Nagara Block soil among the both pedon. The similar finding was given by Gupta et al., (2019).

\section{Organic carbon (\%)}

Data on soil organic carbon table 1 revealed that organic carbon content at different depth of soil in two pedons showed decreasing with increasing soil depth. Nagara Block soil showed maximum organic carbon content $0.59 \%$ at $15-30 \mathrm{~cm}$ depth of pedon- 1 and $0.29 \%$ at $0-15 \mathrm{~cm}$ depth of pedon-2. Pedon-2 was showed organic carbon content ranged between 0.29 to $0.11 \%$ and pedon 1 organic carbon ranged between 0.59 to $0.15 \%$ with higher value in Nagara Block pedon. The similar finding was reported by Sahu and Bala (1995).

\section{Calcium carbonate $(\%)$}

Irrespective of the land use system the extent in profile horizons of calcium carbonate was measured at pedon-1 and pedon-2. The small variation was found in amount of $\mathrm{CaCO} 3$ (Table 1) in all pedons. The data of table 1 revealed that the calcium carbonate content in soil of all pedon depth was showed decreasing ranged from 1.37 to $0.39 \%$ throughout the depth. However, $\mathrm{CaCO}_{3}$ content was found maximum (1.37\%) in surface horizon (15-30 $\mathrm{cm})$ and decreased regularly with soil depth at pedon-1.

The pedon- 2 was showed $0.87 \%$ on $15-30 \mathrm{~cm}$ depth to $0.39 \%$ on sub-surface layer. There was small difference of calcium carbonate in Nagara Block soil between the two pedon of Uraini and Malap village. The similar finding was reported by Gupta et al., (2019).

\section{Available nitrogen (kg/ha)}

The data in table 2 revealed that the available nitrogen content in soil of two pedons. The pedon-1 soil was ranged from 353.9 to 142.2 $\mathrm{kg} / \mathrm{ha}$, from surface $(0-15 \mathrm{~cm})$ horizons to lower depth $(105-130 \mathrm{~cm})$ horizons. Pedon-2 was showed for available nitrogen value 489.8 to $211.7 \mathrm{~kg} / \mathrm{ha}$ from surface $(0-15 \mathrm{~cm})$ horizons to lower depth of $(105-130 \mathrm{~cm})$ horizons.

Its might be due to continuous application of imbalanced chemical fertilizer and cultural practices leads to extent of increased available $\mathrm{N}$ status at Nagara Block, a partial decomposition of crop residues build of available $\mathrm{N}$ and $\mathrm{P}$ with combined use of inorganic and organic sources of fertilizer have also been reported by Bhandari et al.(1992). Similarly, Singh et al (2011) also reported in a study from Darjeeling soil that the status of available $\mathrm{N}$ was higher in top soil compared to sub soil. 
Table.1 Status of soil pH, EC, B.D. WHC, Organic Carbon and $\mathrm{CaCO}_{3}$ of pedons of soil in different in two village of Nagara block soil

\begin{tabular}{c|c|c|c|c|c|c|c|c|c|c|c|c|c|}
\hline $\begin{array}{c}\text { Depth } \\
(\mathrm{cm})\end{array}$ & \multicolumn{9}{|c|}{ Uraini (P1) } \\
& $\begin{array}{c}\mathrm{pH} \\
(1: 2.5)\end{array}$ & $\begin{array}{c}\mathrm{EC}(\mathrm{dSm}-1) \\
(1: 2.5)\end{array}$ & $\begin{array}{c}\mathrm{Bd} \\
(\mathrm{Mgm}-3)\end{array}$ & $\begin{array}{c}\text { WHC } \\
(\%)\end{array}$ & $\begin{array}{c}\text { O.C. } \\
(\%)\end{array}$ & $\begin{array}{c}\mathrm{CaCO} 3 \\
(\%)\end{array}$ & $\begin{array}{c}\mathrm{pH} \\
(1: 2.5)\end{array}$ & $\begin{array}{c}\mathrm{EC}(\mathrm{dSm}- \\
1)(1: 2.5)\end{array}$ & $\begin{array}{l}\text { Bd } \\
(\mathrm{Mgm}-3)\end{array}$ & $\begin{array}{l}\text { WHC } \\
(\%)\end{array}$ & $\begin{array}{l}\text { O.C. } \\
(\%)\end{array}$ & $\begin{array}{l}\text { CaCO } \\
3(\%)\end{array}$ \\
\hline $0-15$ & 7.8 & 1.003 & 1.22 & 37.5 & 0.31 & 0.45 & 8.1 & 1.001 & 1.73 & 35.8 & 0.29 & 0.62 \\
\hline $15-30$ & 7.9 & 1.002 & 1.24 & 34.7 & 0.59 & 1.37 & 7.9 & 1.003 & 1.65 & 34.2 & 0.24 & 0.87 \\
\hline $30-45$ & 7.6 & 1.002 & 1.29 & 31.9 & 0.31 & 0.97 & 7.8 & 1.003 & $1 . .29$ & 32.8 & 0.11 & 0.69 \\
\hline $45-60$ & 7.6 & 1.003 & 1.33 & 28.6 & 0.27 & 0.77 & 7.8 & 1.003 & 1.34 & 29.6 & 0.07 & 0.77 \\
\hline $60-75$ & 7.4 & 1.002 & 1.26 & 24.8 & 0.45 & 0.65 & 7.8 & 1.001 & 1.19 & 27.4 & 0.27 & 0.39 \\
\hline $75-90$ & 7.4 & 1.003 & 1.25 & 22.6 & 0.22 & 0.69 & 7.7 & 1.003 & 1.29 & 26.9 & 0.22 & 0.49 \\
\hline $90-105$ & 7.4 & 1.003 & 1.31 & 21.9 & 0.15 & 0.87 & 7.7 & 1.003 & 1.25 & 23.4 & 0.18 & 0.79 \\
\hline $105-130$ & 7.6 & 1.003 & 1.55 & 20.4 & 0.15 & 0.79 & 7.6 & 1.001 & 1.16 & 22.2 & 0.16 & 0.92 \\
\hline
\end{tabular}

Table.2 Status of available NPK and S in pedons soils at different depth

\begin{tabular}{|c|c|c|c|c|c|c|c|c|}
\hline \multirow{2}{*}{$\begin{array}{l}\text { Soil depth } \\
\text { (cm) }\end{array}$} & \multicolumn{4}{|c|}{ Uraini (P1) } & \multicolumn{4}{c|}{ Malap (P2) } \\
\hline $\mathbf{0 - 1 5}$ & $\mathrm{N}$ & $\mathrm{P}$ & $\mathrm{K}$ & $\mathrm{S}$ & $\mathrm{N}$ & $\mathrm{P}$ & $\mathrm{K}$ & $\mathrm{S}$ \\
\hline $\mathbf{1 5 - 3 0}$ & 341.9 & 13.65 & 336 & 16.25 & 489.8 & 15.28 & 403 & 13.59 \\
\hline $\mathbf{3 0 - 4 5}$ & 268.6 & 12.24 & 280 & 16.20 & 442.4 & 14.64 & 313 & 12.46 \\
\hline $\mathbf{4 5 - 6 0}$ & 230.6 & 11.97 & 291 & 12.46 & 395.0 & 13.87 & 302 & 11.32 \\
\hline $\mathbf{6 0 - 7 5}$ & 183.2 & 11.78 & 280 & 11.75 & 385.5 & 13.38 & 336 & 10.68 \\
\hline $\mathbf{7 5 - 9 0}$ & 164.3 & 11.24 & 259 & 11.28 & 268.6 & 12.97 & 336 & 10.18 \\
\hline $\mathbf{9 0 - 1 0 5}$ & 158.0 & 10.98 & 280 & 10.96 & 252.8 & 12.49 & 291 & 9.76 \\
\hline $\mathbf{1 0 5}-130$ & 142.2 & 9.76 & 313 & 9.84 & 211.7 & 11.93 & 262 & 9.76 \\
\hline
\end{tabular}

Table.3 Status of available (DTPA Extractable) $\mathrm{Fe}, \mathrm{Cu}, \mathrm{Zn}$ and $\mathrm{Mn}\left(\mathrm{mg} \mathrm{kg}^{-1}\right)$ in soil at different soils depth

\begin{tabular}{|l|l|l|l|l|l|l|l|l|}
\hline \multirow{2}{*}{ Depth(cm) } & \multicolumn{9}{|c|}{ Uraini (P1) } & \multicolumn{4}{c|}{ Malap (P2) } \\
\cline { 2 - 10 } & Fe & $\mathrm{Cu}$ & $\mathrm{Zn}$ & $\mathrm{Mn}$ & $\mathrm{Fe}$ & $\mathrm{Cu}$ & $\mathrm{Zn}$ & $\mathrm{Mn}$ \\
\hline $\mathbf{0 - 1 5}$ & 3.10 & 7.85 & 0.62 & 2.55 & 5.23 & 9.07 & 0.50 & 4.83 \\
\hline $\mathbf{1 5 - 3 0}$ & 9.02 & 3.74 & 0.27 & 0.35 & 5.39 & 8.70 & 0.44 & 2.28 \\
\hline $\mathbf{3 0 - 4 5}$ & 7.69 & 6.99 & 0.38 & 1.76 & 7.69 & 9.02 & 0.40 & 2.96 \\
\hline $\mathbf{4 5 - 6 0}$ & 3.20 & 6.30 & 0.34 & 3.98 & 8.97 & 7.74 & 0.49 & 1.41 \\
\hline $\mathbf{6 0 - 7 5}$ & 2.88 & 4.43 & 0.27 & 0.99 & 3.84 & 8.06 & 0.53 & 0.18 \\
\hline $\mathbf{7 5 - 9 0}$ & 2.72 & 4.54 & 1.19 & 2.55 & 4.06 & 0.97 & 0.18 & 0.48 \\
\hline $\mathbf{9 0 - 1 0 5}$ & 3.15 & 7.42 & 0.17 & 1.16 & 5.82 & 1.54 & 0.55 & 0.20 \\
\hline $\mathbf{1 0 5 - 1 3 0}$ & 2.37 & 5.12 & 1.22 & 0.64 & 7.85 & 1.31 & 0.12 & 0.26 \\
\hline
\end{tabular}




\section{Available phosphorus (kg/ha)}

Irrespective of the land use system the extent in horizons of available phosphorus was measured at pedon- 1 and pedon- 2 . The small variation in amount of available phosphorus (Table 2) was found in both pedons. The pedon-2 showed greater amount of available phosphorus $(15.28 \mathrm{~kg} / \mathrm{ha})$ in $0-15 \mathrm{~cm}$ depth and it was decreased with increasing horizon depth up to $105-130 \mathrm{~cm}$ of $9.76 \mathrm{~kg} / \mathrm{ha}$ (Rajeswar and Khan, 2007) then pedon-1 soil. The greater amount of available phosphorus was found in pedon- 1 of $13.65 \mathrm{~kg} / \mathrm{ha}$. So, that in $0-15 \mathrm{~cm}$ depth in no application of phosphorus might have increased the phosphorus fixation capacity of soil under mixed soil and current land use system (Das et al.1993).

\section{Available potassium content (kg/ha)}

The amount of available potassium measured at pedon 1 and pedon 2 (Table 2). Available potassium decreased with increasing in horizons depth at two pedons. Available potassium in pedon-1 was varied from 336 to $259.6 \mathrm{~kg} / \mathrm{ha}$ and in pedon- 2 was showed 403.2 $\mathrm{kg} / \mathrm{ha}$ on surface horizon and $291.2 \mathrm{~kg} / \mathrm{ha}$ on 90-105 cm depth. There was great different of available potassium content in Nagara Block soil between the both horizon of Uraini and Malap village. The maximum available potassium content was found in the surface horizons and showed decreasing trend with increasing horizons depths. It could be attributed to more intensive weathering and release of exchangeable $\mathrm{K}$ and decomposition from organic residues. However, Singh et al.(2017)

\section{Available sulphur content (kg/ha)}

Data (Table 2) revealed that on available sulphur varied with the horizon depth depending upon soil $\mathrm{pH}$ and organic material of soil of both pedons of land use system. Available sulphur in pedon-1 was 16.25 to $9.84 \mathrm{~kg} / \mathrm{ha}$ and soil pedon-2 of 13.59 to 9.25 $\mathrm{kg} / \mathrm{ha}$, respectively. Greater amount of available sulphur was found in surface soil than in sub surface soil resulted from its recycling over the years by plant and subsequent organic matter accumulation (Bhatnagar et al., 2003).

\section{Micronutrients}

Available (DTPA extractable) Iron (Fe), Copper $(\mathrm{Cu})$, Zink ( $\mathrm{Zn})$ and Manganese $(\mathrm{Mn})$ content.

\section{DTPA extractable Fe (mg/kg)}

Data (Table 3) revealed that on DTPA extractable $\mathrm{Fe}$ in different soil depth of pedons were showed decreasing ranged from upper to lower depth of 2.72 to $9.02 \mathrm{mg} / \mathrm{kg}$ throughout the all depth. However, available Fe content was found maximum $9.02 \mathrm{mg} / \mathrm{kg}$ in surface horizons $15-30 \mathrm{~cm}$ there after decreased regularly with soil depth at pedon2 . The greater amount of value has possible due to the accumulation of water and organic material, although the lowest $\mathrm{Fe}$ content was measured $2.72 \mathrm{mg} / \mathrm{kg}$ at pedon 1 with $75-90$ $\mathrm{cm}$ pedon depth. Iron $(\mathrm{Fe})$ content was fairly greater in pedon-2 up to upper surface at 0-15 $\mathrm{cm}$ horizons depth due to greater $\mathrm{Fe}$ accumulation was observed on the surface of pedon-2 and it was gradual decreased with depth and elevation of pedon, the similar finding was given by Tiwari and Mishra (1990).

\section{DTPA extractable $\mathrm{Cu}(\mathrm{mg} / \mathrm{kg})$}

The available (DTPA extractable) $\mathrm{Cu}$ at different soil depth was studies in two pedons of two village. The data showed decreasing range (Table-7) from 0.97 to $9.07 \mathrm{mg} / \mathrm{kg}$ throughout the depth, however, available $\mathrm{Cu}$ 
content was found maximum $(9.07 \mathrm{mg} / \mathrm{kg})$ in surface horizons $(0-15 \mathrm{~cm})$ and decreased regularly with soil depth at pedon-2, although the lowest $\mathrm{Cu}$ content was measured 0.97 $\mathrm{mg} / \mathrm{kg}$ at pedon- 2 with $75-90 \mathrm{~cm}$. The pedon1 was found $3.74 \mathrm{mg} / \mathrm{kg}$ on $15-30 \mathrm{~cm}$ depth to $7.85 \mathrm{mg} / \mathrm{kg}$ on upper horizon. There were greats different of available $\mathrm{Cu}$ content in Nagara Block soil among the two pedons of both villages. The $\mathrm{Cu}$ content in both profile have no proper variation according to the depth (Singh et al., 2014).

\section{DTPA extractable Zn (mg/kg)}

The data (Table-7) revealed that on available $\mathrm{Zn}$ at different soil depth were showed decreasing range from 0.17 to $1.19 \mathrm{mg} / \mathrm{kg}$ throughout the depth.

The pedon- 1 was showed $0.27 \mathrm{mg} / \mathrm{kg}$ on 60 $75 \mathrm{~cm}$ depth to $1.19 \mathrm{mg} / \mathrm{kg}$ on $75-90 \mathrm{~cm}$ depth horizon and pedon-2 was showed $0.12 \mathrm{mg} / \mathrm{kg}$ on $105-130 \mathrm{~cm}$ depth to $0.55 \mathrm{mg} / \mathrm{kg}$ on $90-$ $105 \mathrm{~cm}$ depth horizons. There was great difference of available $\mathrm{Zn}$ content in Nagara Block soil among the two pedons. Available $\mathrm{Zn}$ in both pedons varied from 0.27 to 1.19 $\mathrm{mg} / \mathrm{kg}$. The maximum available $\mathrm{Zn}$ was observed in the surface horizon and showed decreasing trend towards increasing horzon depth. Similar finding are given by gupta $e t$ al (2019).

\section{DTPA extractable Mn (mg/kg)}

The amount of available Mn measured at pedon-1and -2 in Table-7 showed that the available Mn decreased in horizon depth at all pedon from upper to lower depth.

The pedon- 1 was showed $0.35 \mathrm{mg} / \mathrm{kg}$ on 15 $30 \mathrm{~cm}$ depth to $2.55 \mathrm{mg} / \mathrm{kg}$ on $15-30 \mathrm{~cm}$ lower horizon and pedon-2 was showed 4.83 $\mathrm{mg} / \mathrm{kg}$ on $0-15 \mathrm{~cm}$ to $0.18 \mathrm{mg} / \mathrm{kg}$ on lower surface horizon. There was great defence of available Mn in Nagara Block soil among the two pedons (Singh et al., 2014).

\section{References}

Abrol, I.P.; Hole, J.S.P. and Massoud, F.I. (1988). Salt affected soil and their management. FAO Soil Bullletin 39, Rome.

Bhandari, A.L., Sooda, A., Sharma, K.N. and Rana, D.S., (1992). Integrated nutrient management in a rice-wheat system. Journal of the Indian Society of Soil Science. 40:742-74

Bhatnagar, A.K., Bansal, K.N. and Trivedi, S.K., (2003). Distribution of suphurin some profiles of Shivpuri District of Madha Pradesh. Journal of the Indian Society of Soil Science. 51: 74-76.

Das, P.K. Sahu, G.C. Nandu, S.S.K. and Acharya, N. (1993). Effect of soil characteristics on phosphate fixing capacity of some Alfisols. Journal of The Indian Society of Soil Science. 41: 51-56.

Gupta, S.K., Singh, A.K. and Singh, A.K. (2019), Micronutrient status and physical properties of soils of Bairia block of district Ballia, Uttar Pradesh, Asian Journal of Science and Technology, 10, (12), 10529-10531.

Gupta, S.K., Singh, A.K., Singh, A.K., Ranjan,A. and Shukla, N.K.,(2019) Physico-chemical characterization of soils of Bairia block of district Ballia, Uttar Pradesh Journal of Pharmacognosy and Phytochemistry 2019; 8(2): 1445-1448.

Goovaerts, P., (1998). Geo-statistical tools for characterizing the spatial variability of microbiological and physico-chemical soil properties. Biololgical Fertilizer of Soil. 27: 315-334.

Jackson, M. L., (1973). Soil Chemical Analysis, Prentice Hall of India Private Limited, New Delhi.

Kanwar, J.S. and Chopra, S.L. (1998). 
Analytical Agricultural Chemistry (Edn.) Kalyani Publishers, New Delhi

Mandal, A.K. and Sharma, R.C. (2011). Description and Characterization of typical soil monoliths from salt affected areas in Rajasthan. Journal of the Indian Society of Soil Science, 60(1):299-303

Mehta, K.M., Mathur, C.M. and Shankarayana, H.S. (1958). Investigation on physical properties of Kota soil in relation to their erodibility. J. Indian Soc. Soil Sci. 6: 227-232.

Muhr, G.R., Datta, N.P., Sankara subramany, H., Laley, V.K. and Donahure, R.L. (1965). Soil Testing In India USAID, New Delhi.

Olsens, S.R., Cole C.V. Watanable, F.S. and Dean, L.A. (1954). Estimation of available phosphorus in soils by extraction with sodium bicarbonate. United States Department of Agriculture Circular 939.

Puri, A.N. (1930), A new method for estimating total carbonates in soils. Imp. Agric. Res. Pusa Bull, pp. 7.

Rajeswar, M. and Khan, M.A. Aariff.(2007). Physico- chemical properties and available macro and micronutrients in the soils of Garikapadu research station of Krishna District of Andhra Pradesh, India. An Asian Journal of Soil Science. 2(2): 19-22.

Sahu, G.C. and Bala, N. (1995). Characterization and classification of soil on valley plains of middle
Andman is land. Journal of the Indian Society of Soil Science. 43(1):99-103.

Sen, P., Majumdar, K. and Sulewski, G. (2008). Importance of spatial nutrient variability mapping to facilitate SSNM in small land holding systems. Indian J. Fertilizer, 4(11): 43-50.

Sibbiah, B.V. and Asija, G.L. (1956). A rapid method for the estimation of available Nitrogen in soils. Current science, 25: 259.

Singh AK, Bisen JS, Bora DK, Kumar R, Bera B. (2011) Comparative study of organic, inorganic and integrated plant nutrient supply on the yield of Darjeeling tea and soil health. Two and a Bud; 58:58-61.

Singh AK, Pathak SK. (2017). Potassium in tea soil (Camellia sinensis (L) O. Kuntze) cultivation from soil to cup quality-A review. Agricultural Reviews. 39(1): 219- 227.

Walkley A, Black IA. (1934). An examination of the direct of method for determining soil organic matter and a proposed modification of titration method. Soil Science.; 34:29-38.

Williams, C.H. and Steinbergs, A. (1959). Soil sulphur fractions as chemical indices, A. and Black, I.A. (1934). An examination of the Degtijareff method for determining Soil Organic matter and a proposed modification of titration method. Soil Science. 37: 2938.

\section{How to cite this article:}

Divakar Singh, Ashok Kumar Singh, Anil Kumar Singh and Sandip Kumar Gupta. 2020. Characterization of Rice Growing Soil of Nagara Block of Ballia District (U.P.), India. Int.J.Curr.Microbiol.App.Sci. 9(04): 575-581. doi: https://doi.org/10.20546/ijcmas.2020.904.070 